\title{
Grundtvig, Laub og kirkesangen
}

\author{
Af Peter Thyssen
}

Ligesom Danmark i Grundtvig finder sin største salmedigter i en tid, hvor det mindst skulle være at vente, nemlig i århundredet efter Oplysningen, således er også den mest betydningsfulde danske salmekomponist, Thomas Laub (1852-1927), at finde på et tidspunkt, hvor fænomenet »kirkemusik « ikke længere var genstand for nogen sagligt orienteret begrebsdefinition. Som det lykkedes Grundtvig at genoplive salmesangen efter det 18. århundredes kirkelige forfaldsperiode, således opnåede Laub at skabe fornyet klarhed om, hvad man kan betegne som gudstjenestens musikalske stil. Og som Grundtvigs salmer er blevet et bærende element i den danske gudstjeneste, er også Laubs melodier kommet til at stå som en urokkelig bestanddel af den danske kirkesang.

At der således med Grundtvig og Laub kan iagttages et sammenfald i kirkesangens poetiske og musikalske fornyelse, er ikke nogen tilfældighed; af Laubs 100 originale salmemelodier er de 68 skrevet til tekster af Grundtvig. ${ }^{1}$ Spørgsmålet er imidlertid, hvordan dette »samarbejde« nærmere lader sig bestemme. Tesen lyder her, at når Laubs melodier i adskillige tilfælde har vist sig at være kongeniale med Grundtvigs salmer, skyldes det ikke blot, at Laub har komponeret melodier til tekster af Grundtvig (det har så mange gjort i tidens løb); det skyldes i lige så høj grad, at Laubs arbejde med kirkemusikken og den kirkemusikalske tradition i flere henseender udgør en pendant eller en parallel til Grundtvigs arbejde med salmetraditionen. Dette »parallel-forl $\varnothing b$ «bliver det i det følgende opgaven at overveje nærmere, for på den måde at tegne et omrids af tilblivelseshistorien bag noget af det allermest originale i den danske kirkesang.

\section{Teologi og poesi i Grundtvigs salmedigtning}

I modsætning til al anden digtning, må det som et ufravigeligt krav stilles til salmedigtningen, at den bevidst vælger sig kristendommen og den kristne tro som sit hovedtema. Det forudsætter imidlertid et reflekteret forhold til, hvad der er kristendommens væsen og egenskaber, dens grundsætninger og målsætninger, kort sagt: en teologi. 
Her skal det pointeres, at de teologiske refleksioner, der er en nødvendig betingelse for, at kristendommen kan gøre sig forståelig også i salmepoesien, ingenlunde behøver at være udtænkt af digteren selv. Den for salmedigtningen obligatoriske teologi kan meget vel være formuleret af andre, når blot digteren formår at tage den til sig som sin egen.

Som eksempel på noget sådant kan nævnes både Kingo og Brorson. Det gælder for begges vedkommende, at de næppe har udtænkt noget af egentlig teologisk originalitet. Det havde de forresten heller ikke noget behov for. Datidens teologi (der vel intuitivt fornemmede, i hvilken retning det gik med fremspiringen af de nye naturvidenskaber) var overordentlig ambitiøs, såvel på det teoretiske som på det praktiske plan, og frem for alt var den kontant og præcis i formuleringen af sine læresætninger. Det var altsammen noget, Kingo og Brorson kunne tage til sig som deres eget, for da til gengæld at kunne investere hele energien i teologiens poetiske udtryk. Netop denne fortrolighed med teologiens dogmatiske grundsætninger forekommer især vigtig for forståelsen af Brorsons kristent-poetiske univers. Når Brorson formåede at fylde sin salmedigtning med denne gevaldige række af sublime poetiske billeder, skyldes det ikke blot hans særlige digteriske evner; det må i mindst lige så høj grad tilskrives det forhold, at Brorson i sine salmer uophørligt gør brug af kristne temaer, der gennem århundreders teologiske tankevirksomhed var blevet forarbejdet, poleret og slebet til, så de nu for digteren var blevet nemme og smidige at håndtere. Brorsons posthumt udgivne Svanesang fra 1765 er ikke kun hans egen; den kan i grunden også opfattes som en tusindårig teologisk traditions »svanesang «.

Fyrretyve år efter Brorsons Svanesang gjorde den unge Grundtvig sin entré i den teologiske debat med afhandlingen $\mathrm{Om}$ Religion og Liturgie (udgivet 1807). Grundtvigs første trykte teologiske afhandling er et romantisk opgør med den teologiske rationalismes gudstjenesteforståelse; skrevet med konkret anledning i biskop Boisens Plan til en Forbedring af den offentlige Gudstjeneste fra 1805. Hvad Grundtvig her angriber, er primært oplysningsteologernes syn på kristendom og religion som et vedhæng til moralfilosofien; noget, der i liturgisk henseende gav det etisk-belærende den absolutte forrang fremfor det "poetisk-opløftende«.

Nok så vigtigt er det imidlertid, hvordan Grundtvig allerede på dette tidlige tidspunkt også retter angreb mod et romantisk, pan- 
teistisk farvet religionsbegreb, hvor poesien som sådan bliver til en himmelstige for »det endeliges« forening med »det uendelige«.

Poesien veed vel at konstruere en høiere Tilværelse af de meest glandsfulde Træk, hvori Mennesket øieblikkelig bevæger sig med berusende Vellyst, men den kan ikke skiænke noget varigt Liv i samme, og ei tillægge Exsistencen en egen Værdie, som indsluttende Betingelsen for en høiere Væren. Er nu dens Tendents, at udrive Mennesket af Tilværelsen, kan den ei heller løse dennes Gaader, der tvertimod træde stærkere frem, jo nærmere den kommer sit Maal. ${ }^{2}$

Kunsten (poesien) udmærker sig altså ved at »udrive Mennesket af Tilværelsen«, til fordel for en momentan, æstetisk »beruselse«. Netop fordi kunsten fungerer som »det Andet «, der har sit virke i den 'æstetiske suspendering' af menneskets hverdagsagtige tilværelse, vil man aldrig kunne tilskrive kunsten nogen forklarende virksomhed i forhold til den menneskelige eksistens. Jo mere kunsten nærmer sig sit eget mål som kunst, dvs. i frembringelsen af en »høiere Tilværelse af de meest glandsfulde [æstetiske] Træk «, desto mindre formår den at sige noget konkret om den dennesidige tilværelse, samt løsningen af dennes »Gaader«. I teologisk henseende kan kunsten eller poesien derfor kun have betydning som en art ubestemmelig forjættelse om, at der »paa hin Side Havet maa være et Land, med skiønnere Vexter, og renere Luft - vort egentlige Hiem « ${ }^{3}$; hin »dunkle Ahnelse«, som hverken filosofien (med sin focusering på de synlige ting) eller poesien (med sin stræben mod det usynlige) er i stand til at indfri.

I forlængelse af denne tolkning, må Grundtvigs tanker om poesien i Om Religion og Liturgie snarere siges at forudgribe, fremfor at modsige den kunstopfattelse, der kommer til udtryk i De levendes Land (1824); især vers 5:

\section{O, skuffende Drøm}

Du skinnende Boble paa Tidernes Strøm, Forgæves dig Skjalden med Mund og med Pen Af glimrende Skygger vil skabe igien, Naar Skyggen er ligest, da hulke de Smaa

Som stirre derpaa 
Skjaldens forsøg på at virkeliggøre drømmen om »Landet bag Hav« ud af »glimrende Skygger « er på forhånd dømt til at mislykkes fordi jo mere digteren sætter ind på at skabe astetiske skyggebilleder, desto mindre fungerer disse billeder som afskygningen af noget værende.

Der er således al mulig grund til at tilslutte sig Christian Thodbergs tolkning: at »ligest « her betyder »mest lodret « (og ikke »ligner mest «). ${ }^{4}$ For den første forklaring taler som sagt, at jo klarere den "poetiske sol « skinner, desto mindre fungerer den som et skyggebillede af noget værende (dvs. kaster overhovedet ikke nogen skygge, men fungerer som intet andet end - l'art pour l'art). I mod den anden udlægning taler, at de »Smaa" strengt taget ikke havde haft nogen grund til at »hulke«, dersom de fik malet et skyggebillede for $\varnothing \mathrm{je}$, der »lignede mest « - det burde dog snarere have givet anledning til glædesudbrud at være kommet så tæt på »sagen selv«!

Synes det dermed muligt at iagttage overensstemmelser i Grundtvigs syn på poesien i Om Religion og Liturgie og i De levendes Land, kan det samme næppe siges om teologien i de to værker. Hvor Grundtvig i digtet De levendes Land præsenterer intet mindre end en teologisk afklarethed (Gudsrigets komme i Guds åbenbaring i Kristus), befinder Grundtvig sig i 1807 snarere på det teologisk søgende plan (religion bestemmes generelt som »det Endeliges forening med det Evige«; den kristne religion specielt som »det Endeliges forsoning med det Evige ${ }^{5}$ ). Denne romantiske sværmen for modsætningsparret »endelighed - uendelighed «; »timelighed - evighed « præger da også Grundtvigs overvejelser over liturgiens (gudstjenestens) praktiske indretning i Om Religion og Liturgie. Grundlæggende gælder det, at gudstjenesten består af en oplфftende ("poetisk «) og en undervisende (»filosofisk «) del; dog altid således, at den første har forrang fremfor den sidste. ${ }^{6}$ Til den »opløftende-poetiske« del hører naturligt nok salmesangen:

Nu komme vi til Sangen, Middelpunkten af den liturgiske Poesie. Her maa alt hvad Mennesket kan frembringe Høit og Skiønt, forene sig. Poesien maa træde frem, klædt i det harmoniske Vers, hvilende paa melodiske Riim, og hævet ved den potenserende Musik. Høit over Jorden maa vi opløftes, og et Glimt af det evige Liv maa svæve forbi vort mod Himlen stirrende Øie. ${ }^{7}$ 
Uden den forudgående relativering af poesiens kvaliteter $\mathrm{i}$ teologisk henseende, ville man her tro sig stillet over for en rendyrket romantisk kunstreligiøsitet, hvor den "poetiske harmoni« (i ord såvel som i toner) som sådan formår at berede beskueren en himmelflugt og »et Glimt af det evige Liv«. Det er dog ingen grund til at formode andet, end at Grundtvig allerede på dette tidlige tidspunkt har opfattet salmepoesien som en art 'teologiens forgård', således at poesien med en let omskrivning af Grundtvigs reference til Schiller - »bør fremhielpe « teologien (Schiller: moraliteten) »ved den ophøiede Stemning, hvori den sætter Mennesket« (s. 167 sst.). Når salmesangen i Om Religion og Liturgie begrænser sig til betragtninger over den poetisk-æstetiske side af sagen, må det vel igen føres tilbage til den unge Grundtvigs teologiske uafklarethed; nogen egentlig indholdsmæssig bestemmelse af salmesangen har på dette tidspunkt ikke været mulig.

Når det alligevel er blevet fundet det vigtigt at gøre dette ophold ved Grundtvigs tidligste teologiske skrift, har det været for at antyde, hvordan Grundtvig fra første færd var sig nogle afgørende problemstillinger bevidst. I første omgang reagerer han kraftigt mod datidens fornufts-religiøsitet; reduceringen af kristendommen til et moralfilosofisk appendix yder hverken i menneskelig eller i kristelig henseende sagen tilstrækkelig retfærdighed. Men nok så vigtigt er det, at den romantiske opdagelse af »følelsen«, »fantasien« og »evighedslængselen« hos Grundtvig ikke uden videre omsættes til romantisk-æstetiske kategorier; med poesien som højeste mediator mellem det timelige og det evige. Grundtvig er klar over, at poesien aldrig kan give konkrete bud på løsningen af »Tilværelsens Gaader«. Kunne den nemlig det, ville den ikke længere være poesi, men derimod få karakter af filosofi (der på sin side da til gengæld aldrig vil kunne indfri menneskets evighedslængsel). Hvad der mangler, er en instans, der rummer både poesiens dimension af evighed og filosofiens aspekt af timelighed. Der mangler kort fortalt et »levende ord «!

Den udviklingslinie, der hermed er urgeret fra Grundtvigs tidlige, romantiske periode frem til Grundtvigs »mageløse opdagelse« $\mathrm{i} 1825$, blev midlertidig afbrudt, da Grundtvig (af personlige-eksistentielle årsager) i 1810-11 søgte tilbage til »fædrenes religion«; den gammellutherske kristendom.

Dette førte samtidig en fornyelse i Grundtvigs salmesyn med sig. Grundtvigs allerførste salme De hellige tre Konger (»Dejlig er den 
himmel blå ) fra december 1810 er således skåret efter lutherskkingosk model: fortælling fra Bibelen med aktualiserende anvendelse; jvf. salmens to sidste vers:

Stjernen ledte vise Mænd

Til nyfødte Konge hen,

I har og en saadan Stjerne,

Og naar I den følger gierne,

Komme I til Jesum vist.

Denne Stjerne, lys og mild,

Som kan aldrig lede vild,

Er hans Guddomsord det klare

Som han os lod aabenbare

Til at lyse for vor Fod.

Salmen blev udgivet i april 1811 og forsynet med et interessant forord, der programmatisk giver udtryk for Grundtvigs nye salmebegreb. Indledningsvis gør Grundtvig rede for, hvilken slags salmer, De hellige tre Konger tilhører, »nemlig de historisk-kristelige. I Lutherdommens første halvtredie Aarhundrede udgjorde saadanne den største Del af de forordnede Psalmer, og mig tykkes, med Rette, da den historiske Psalme er at ligne ved en rindede Bæk, og den dogmatiske eller moralske derimod langt ligere de stillestaaende Vande. $\aleph^{8}$ Grundtvig bruger tydeligvis udtrykket historisk-kristelig i bevidst modsætning til evangelisk-kristelig (og dermed i polemik mod salmerne i Evangelisk-kristelig-Psalmebog fra 1798). Hvor ordet »evangelisk « hos Grundtvig her står for det dogmatisk-belærende (med den kantianske moralfilosofi som hovednøglen til de bibelske skrifter), da betyder ordet »historisk « i denne sammenhæng de bibelske beretningers reaktualisering her og nu (med de bibelske fortællingers egne intentioner som hovedkraften).

Grundtvig anbefaler da på det kraftigste en tilbagevenden til den »historisk-kristelige« salme, fremfor den såkaldte »evangelisk-kristelige $\ll$;

... dersom vi endnu længere ville vedblive at ringeagte sand Kristendom og daarligen sysle med at opelske et Kundskabstræ af den halvvisne Gren, som er løsrevet fra sin hellige Rod, da 
vil Slægten snart vorde udjaget af sit drømte Paradis, uden anden Vinding end den raadnende Frugt, den Stjal med formastelig Haand, og da vil den forgæves længes efter det foragtede Livets træ .... ... Under den Forudsætning, at der endnu ere mange Tusinder i Norden, som ei have bøiet Knæ for Tidens livløse Afgudsbilleder, men som dog kunne trænge til at størkes i Troen og Haabet, troer jeg, at en Samling af kristelige, mest historiske Sange vilde være Mange kjærkommen, og en saadan agter jeg at udgive, om Gud under Liv og Helsen. Endel skulle være selvgjorte, men den største Del borgede af Kingo, Luther, og flere af de ældre kristelige Digtere med de Forandringer, Tiden med Ret kan fordre. ${ }^{9}$

Det gælder altså for Grundtvig primært om at genoplive salmesangen fra Luther og Kingo, for da på denne grund at skabe de nye, der måtte være behov for. Her finder vi således den første 'programerklæring' for det gevaldige arbejde med den gamle salmetradition, der kom til at stå som Grundtvigs hovedindsats, omend han først adskillige år senere for alvor fik dette program ført ud i livet - og formentlig i en noget anderledes skikkelse, end han havde forestillet sig i 1811 .

Grundtvigs programmatiske venden tilbage til den gammellutherske kristendom i årene 1810-1820 gjorde ikke hans indædte modstand mod oplysningstiden og dens tænkere mindre. Som et vigtigt led i forsøget på at få skovlen under disse, kan man også opfatte hans bestræbelser på at rehabilitere en før-moderne metafysik, som det især finder sted i Dannevirke-afhandlingerne (1816-19). Meget slagordsagtigt kunne man imidlertid hævde, at Grundtvig her ender med at blive fanget i sit eget spind; beskæftigelsen med den nyere tids filosofihistorie fører ham uvægerligt frem til hans oprindelige udgangspunkt, nemlig romantikken og den romantiske æstetik. Sagt på en anden måde: Grundtvig forbliver alligevel fastholdt på den moderne problematik, der består i, at det ikke er muligt at slutte sig til en forening af jordisk og himmelsk, timeligt og evigt osv. ad erkendelsens vej (som det var tilfældet i den gamle metafysik). En sådan forening kan derfor kun tilvejebringes som åbenbaring; dvs. formedelst en instans, der i sig selv består af en sådan sammensmeltning. Det var, hvad de tidlige romantikere (Schelling o. a.) mente at finde i kunsten og »det æstetiske« (frem for alt i poesien 
som sammensmeltningen af kognitive udsagn og æstetiske former). Og det var, hvad Grundtvig fandt i billed-ordet, som han teologisk definerede som »det åbenbarede ord«:

I det aabenbarede eller prophetiske Ord; aabenbaret, fordi det udsiger noget Hemmeligt, prophetisk, fordi Hemmeligheden i sin Tid skal opdages, i det har vi baade hvad Konsten skal danne, og fornemmelig danne i, men hvor er nu Konsten? For at finde den, maae vi ikke blot see, men tillige høre BilledOrdet, og høre det synge. Sang, det sige Fuglene os, er den naturligste af alle Konster, altsaa Konsten i sin Natur: Udtrykket af den rene Sandselighed, Skaber-Ordets vingede Lyd, der flagrer mod Himlen og kalder smeltende paa Ordet hvorfra det er adskilt. Hvergang Fuglen synger os over Hovedet, da er det som om den følde, og vilde minde os om at i Mennesket er det store Møde kommet i Stand, og at der skal den hellige GienForening gaae for sig. ${ }^{10}$

Det afgørende i denne passus er den betydning, sangen eller musikken tillægges i forhold til »billed-ordet «. Lyden er den kraft, der giver ordet (»åbenbaringens legeme ${ }^{11}$ ) liv - og dermed gør det umiddelbart nærværende for mennesket.

Skulle man herfra forsøge at trække en forbindelse til Grundtvigs videre udvikling, kunne man måske sige, at Grundtvigs »mageløse opdagelse« i 1825 af »det levende ord «, som det har lydt i kirken siden apostlenes dage, også kan være blevet forberedt gennem hans tanker om »billed-ordet « fra Dannevirke-perioden. Forestillingen om Herrens eget levende Ord ved dåben og nadveren kunne da tolkes som den konkretiserende og personificerende overbydning af Dannevirke-afhandlingens mere akademisk-abstrakte overvejelser over det poetiske billed-ord. I hvert fald kan der fra begyndelsen af 1820'erne iagttages et nybrud i Grundtvigs teologi- og gudstjenesteforståelse. ${ }^{12}$ Det synes her som om, at Grundtvigs opfattelse af sangen som en livskraft har fået en langt større rækkevidde, end det oprindeligt var tilfældet i den omtalte Dannevirke-afhandling. Sangen skal mere end blot minde om »det store Møde« mellem Skaber og skabning; salmesangen bliver ydermere det sted, hvor den »hellige Gien-Forening « skal foregå. Ligesom Herren i gudstjenesten er levende til stede i sit Ord, ligeså levende skal også menighedens åbenlyse tilkendegivelse 
af at være blevet tiltalt være. Salmesangen er med andre ord blevet en teologisk-kirkelig hovedhjørnesten.

Fra den tid sker der også et omskift i Grundtvigs forhold til de gamle salmer. Hvor det tidligere (i 1811) primært gjaldt om en genoplivning af den gamle salmetradition, bliver der nu i stigende grad tale om en egentlig fornyelse af salmesangen; svarende til Grundtvigs nye kristendomssyn med den gudstjenstlige virkelighed, »nådens tid «, som det centrale.

Monumentet over Grundtvigs salmedigtning blev som bekendt Sang-Vark til den danske Kirke fra 1837; et projekt, der vel fik sin hovednæring fra Grundtvigs genopdagelse af den gamle græske gudstjeneste med dens dramatiske islæt. ${ }^{13}$ Men hvorom alting er, så er Grundtvigs salmedigtning fra og med Sangværket (såvel originalsalmerne som salmebearbejdelserne) gennemglødet af hans egen teologi; en teologi, der ikke blot forstår at bruge den »poetiske harmoni« som æstetisk-retorisk middel, men som ydermere i selve den gudstjenstlige sang ser kristendommens egentlige frelsesvirkning: menneskets nyskabte evne til at 'tale med Gud som sin næste'!

Til afrunding en opsummerende sammenfatning. Den her skitserede udvikling i Grundtvigs opfattelse af forholdet mellem teologi og poesi kan anskues som et udviklingsforløb i tre trin. Det »1. trin« er at finde i Grundtvigs romantisk-æstetiske opgør med oplysningstidens teologiske rationalisme. Her er han på linie med så mange af sine tyske samtidige. Det »2. trin « kan bestemmes som Grundtvigs teologisk-historiske opgør med romantikernes panteistisk farvede religiøsitet. ${ }^{14}$ Også her finder Grundtvig åndsfæller i Tyskland og i andre protestantiske lande; den romantisk-historiske interesse for den gammellutherske tradition (salmer, liturgi osv.) er kendetegnende for 1800-tallets kirkeliv over alt i det protestantiske Europa (tilsvarende interesser fandtes naturligvis i den katolske verden). - I store dele af den ikke-dansksprogede kirkehistorie bliver Grundtvig derfor i regelen fremstillet som repræsentant for det 19. århundredes 'kirkelige historicisme'; en beskrivelse, der kan være forstålig, men som ikke desto mindre er overfladisk, for ikke at sige misvisende i forhold til Grundtvigs egentlige teologiske indsats. - Her er det netop, at det $\gg 3$. trin « bliver relevant; nemlig Grundtvigs »mageløse opdagelse« af det levende Ord, som det lyder i den kristne gudstjeneste. At Grundtvig således ender i en konsekvent Guds Ord-teologi, må ikke mindst 
tilskrives de vanskeligheder, der knyttede sig til restaureringen af en før-moderne, luthersk kristendom. Det gjaldt primært læren om verbalinspirationen og realprasensen; grundpillerne i den gammellutherske teologi. Grundtvig endte som bekendt med at forkaste begge dele - fordi de metafysiske forudsætninger, der i sin tid udgjorde garantien for teologiens lære herom, ikke længere var forhånden, ligeså lidt som disse forudsætninger lod sig rekonstruere. Hos Grundtvig bliver da såvel den guddommelige sandhed (den gamle mening bag læren om verbalinspirationen) som det guddommelige narvar (realpræsensens oprindelige betydning) sammenfattet og videreført i tanken om det levende Guds Ord: »ordet « som sandhed (johannæisk fortolket) og »levende « i betydningen narvarende.

På den måde lykkes det Grundtvig at rehabilitere urgamle temaer, der teologisk set er helt uomgængelige, men som for Grundtvig ikke længere kunne gøre fyldest i deres traditionelle udformning og begrundelse. ${ }^{15}$ Det samme var tilfældet med salmesangen; den skulle genoplives $\mathrm{i}$ dens oprindelige funktion som menighedens svar på Guds henvendelse til mennesket i evangeliet, men dette krævede nu en indsats, der gik langt ud over reparationen af de skader, som 1798-salmebogen havde forvoldt. Grundtvig måtte med andre ord følge sin teologi op af sin egen, ligeså selvstændige poesi. - En redegørelse for den egentlige rækkevidde af dette forehavende kræver detail-gennemgange, der ligger uden for denne fremstillings rammer. Det vigtigste er i denne sammenhæng da også at fastslå, at det er Grundtvigs teologiske udvikling, der ligger til grund for hans salmepoesi; en konstatering, der bliver af vital interesse, når vi kommer til det næste tema: spørgsmålet om melodierne til Grundtvigs kirkelige poesi.

\section{Den romantiske Grundtvig-sang}

For at forstå det revolutionerende i Grundtvigs genoplivning af salmesangen, må man først holde sig datidens kirkelige tilstande for $\varnothing j e$. Det kan måske bedst illustreres med et citat af Rudolph Bay, kantor ved Holmens Kirke, fra hans lille bog, Om Kirkesangen $i$ Danmark og Midlerne til dens Forbedring fra 1840. Bay beskriver her den almindelige tilstand på følgende måde: 
Almuen synger af Naturen slet; de høiere Classer ikke meget bedre, og tage for størstedelen eiheller Deel i Sangen i Kirken, deels fordi de ansee Prædiken for den eneste væsentlige Deel af Gudstjenesten, deels af Undseelighed for at lade deres Stemme høre, og deels fordi det nu er gaaet af Moden og kaldes gammeldags, ligesom Bordbønner m. m., og endeligen, fordi de ei kiende Psalmemelodierne, og i det hele ansee Choraler for den allerkjedsommeligste og meest smagløse Musik. (s. 17)

Det var til denne situation, Grundtvigs Vartov-menighed kom til at udgøre et fornyende alternativ. I Vartov, hvor Grundtvig blev prædikant i 1839, havde han som bekendt mulighed for at lade sine egne salmer afsynge, idet man her ikke var bundet af de officielle salmebøger. De salmer, Grundtvig havde skrevet på gamle salmemetre (og dermed til gamle melodier), kunne naturligvis umiddelbart synges $\mathrm{i}$ gudstjenesten. Problemet opstod med de salmer, Grundtvig havde digtet til egne versemål; her stod man så godt som helt uden melodistof. Man greb da til den hurtigst tænkelige løsning, idet man tog, hvad man kunne få fat på af melodier fra datidens populærmusik (og i $\emptyset$ vrigt skar nogle nye til i den samme tone). En tid lang kunne man således synge »Blomstre som en rosengård « på melodien til »Kommer hid, I piger små !

Den slags faldt naturligt nok mere konservativt indstillede organister og kirkemusikere for brystet, hvilket bl.a. kommer til udtryk i den første officielle koralbog, der var inspireret af Grundtvig-sangen, nemlig Berggreens Koralbog fra 1853. Berggreen, der var organist ved Trinitatis Kirke, slår i sin indledning, Om Menighedssangen, kraftigt til lyd for, at salmemelodierne må have en »kirkelig karakter«. Det lyder i Berggreens indledning:

Den Idee, der har ledet mig, er: Opnaaelsen af en liveligere Kirkesang uden at opgive den kirkelige Charakteer. Thi medens vist Alle ere enige i Opfattelsen af Kirkesangens Hensigt: at sætte Sindet i en religiøs Stemning, - saa hersker der megen Forskjellighed i Begrebet om Kirkesangens Væsen, og Nogle ere [Vartovfolkene], under den priisværdige Bestræbelse efter at opnaa hin Hensigt [kirkesangens »livelighed «], slaaede ind paa Veje, som jeg ikke kan ansee for de rette, idet der visselig bør drages en skarp Grændse imellem verdslig og kirkelig Sang. Kirkemelodierne bør 
altid være folkelige; men Folke-Melodierne ere ikke altid kirkelige. $^{16}$

Berggreen kunne også godt have sine grunde til at efterlyse en »liveligere« salmesang! Ikke alene var de gamle salmemelodier op gennem det 18. århundrede blevet gjort konsekvent isorytmiske; denne sang på lige lange nodeværdier hele vejen igennem skulle tilmed foregå i det langsomst mulige tempo. - Dette langsomme tempo, hvor melodien på det nærmeste bliver uigenkendelig, har sin ideologiske forankring i den romantiske forestilling om, at kirkemusikken først og sidst skulle befordre andagtsfølelsen hos den enkelte kirkegænger; musikken kunne på ypperlig vis bidrage til at give »smag for det uendelige « (Schleiermacher). En sådan 'følelse for det uendelige' lod sig i kirkemusikken da angiveligt bedst formidle via brede og langsomt flydende tonestrømme!

Det hedder stadig i Berggreens koralbog fra 1853, at »PsalmeMelodiernes Bevægelse altid bør holde sig inden for Langsomhedens Begreb « (s. XVIII). Derfor har han også angivet metronom-tal over hver melodi i koralbogen. Det klassiske eksempel er »Vor Gud han er så fast en borg «. Den har hos Berggreen M.M.-tallet 66 (66 fjerdedele pr. minut). Det er noget langsommere, end man ville synge denne salme $\mathrm{i}$ dag, hvor vi ville bruge noget i retning af M.M. 76 (dvs. svarende til et vers pr. minut). Den afgørende forskel er imidlertid, at salmen hos Berggreen er noteret i halvnoder, hvilket altså vil sige, at den efter Berggreens angivelse skal synges mere end dobbelt så langsomt, som det er tilfældet i dag - nærmest med vejrtrækning på hver stavelse. Altsammen noget, der er med til at give et billede af, hvad Berggreen og hans samtid forstod ved kirkesangens »livelighed «!

Berggreen slutter sin indledning med det fromme $ø$ nske: »Herren lægge sin Velsignelse til vor Gjerning, at Hjerterne under disse Toner maatte røres til Andagt; Tro, Haab og Kjærlighed levendegøres, og et Tempel til hans Ære rejse sig i vort Indre!« (s. XXIII). Det berggreenske synspunkt er for $\emptyset v r i g t$ ganske repræsentativt for tidens kirkemusikalske begreb; i de første 50 år efter at Grundtvig havde udgivet sit Sangværk forblev det den herskende opfattelse i dansk kirkeliv, at kirkesangens musikalske dimension primært har til opgave at »røre menigheden til andagt $\ll$ ! 
Det var først, da Thomas Laub fremsatte sit reformprogram for den danske kirkesang omkring århundredets slutning, at der for alvor blev formuleret et alternativ til denne opfattelse; et alternativ, der ydermere kom til at sætte spørgsmålstegn ved den romantiske Grundtvig-sang som helhed betragtet.

\section{Thomas Laubs reformprogram for den danske kirkesang}

Det må ses som en følge af Grundtvigs originalitet, at den kirkelige udvikling i Danmark fra 1830'erne tog en anden drejning end i de omkringliggende lande. Hvor der allerede fra omkring 1820 i Tyskland opstod reformbevægelser på det liturgiske område (genskabelsen af de gamle liturgiske led osv.), blev den liturgiske udvikling i Danmark i det 19. århundrede afgørende domineret af det grundtvigske gudstjenestesyn (først i 1912 lykkedes det biskop Peder Madsen at få »rådet bod « på det forsømte!). Noget tilsvarende gælder for udviklingen inden for kirkemusikken. For at anskueliggøre dette, skal nogle træk af det 19. århundredes kirkemusikalske udvikling kort skitseres.

I kølvandet af romantikkens historiske interesse for den gamle katolske kirkemusik (Palestrina o. a.) fulgte fra 1820'erne en voksende interesse for den specifikt evangeliske kirkemusik, hvilket naturligvis først og fremmest vil sige: den lutherske koral og den reformatoriske menighedssang. Kildestudier åbnede $\varnothing j n e n e$ for tre grundlæggende temaer og problemfelter vedrørende den reformatoriske kirkesang: 1) de reformatoriske melodiers oprindelige rytmik (contra eftertidens »stive «, isorytmiske koral); 2) de reformatoriske melodiers oprindelige kirketonale melodik og harmonik (contra den senere tids dur/mol-udjæuning af den gamle kirketonalitet), 3) de reformatoriske melodiers forbindelse til og afhængighed af den middelalderlige folkesang.

Det epokegørende arbejde inden for dette område blev den preussiske jurist og musikolog, Carl von Winterfelds Der evangelische Kirchengesang und sein Verhältnis zur Kunst des Tonsatzes, I-III, der udkom i årene 1843-1847. Den overordnede tese hos von Winterfeld lyder, at den evangeliske kirkesang opstod som en sammensmeltning af gammelkirkelig (gregoriansk) sang og middelalderlig folkesang. Denne forening af gregoriansk og folkelig sang ser Winterfeld end- 
videre som et komplementar -forhold. Det skal forstås på den måde, at såvel den gregorianske som den folkelige musik i den evangeliske kirkesang gensidigt supplerer hinanden: den gregorianske kirkesang beriges med folkesangens rytme (og dermed kantabilitet), mens den folkelige sang i den reformatoriske kirkesang suppleres med den latinske sangs rigere tonalitet - i modsætning til folkemusikkens iboende stræben mod tonal forenkling i den joniske og den æoliske skala (»dur« og »mol«), sådan som von Winterfeld mente at kunne iagttage det.

Dette kirkemusikalske princip bliver imidlertid fortrængt med fremkomsten af den italienske dramamusik omkring år 1600, hvor musikken som musica rappresentativa i stigende grad sigter på tekstlig deklamation, fremfor renaissance-musikkens stræben mod den rene »musikalske organisme«. For Carl von Winterfeld bliver det begyndelsen til den evangeliske kirkesangs »forfald «, idet den reformatoriske kirkesangs komplementaritet af kirkelig melodik og folkelig rytmik hermed sættes til side til fordel for en (af operamusikken inspireret) »kunstmusik«, der hverken er kirkelig eller folkelig. Kun hvor det "gamle« kirkemusikideal er bibeholdt, kan Winterfeld tilkende det 17. århundredes kirkemusik en betegnelse som autentisk »evangelisk kirkemusik « - mønstereksemplet på den sådan undtagelse er Paul Gerhardt-komponisten, Johann Crüger (1598-1662).

Fra 1870'erne undergik det winterfeldske kirkemusikideal i Tyskland imidlertid en kraftig revision. Det drejer sig i al korthed om, at begyndelsestidspunktet for »kirkemusikkens forfald« flyttes fra 1600 til 1750. Winterfelds bestemmelser blev fundet for snævre; ikke mindst fordi de udelukkede stort set hele orgellitteraturen fra det 17. og 18. århundrede. Hertil kom endvidere det fornyede billede af Bach, som det tegnedes af Philipp Spitta i hans epokale Bach-biografi i to bind (Leipzig 1873 og 1880), hvor Bach ikke alene lyses i kuld og $k \emptyset n$ som kirkemusiker, men tillige får tildelt prædikatet af »Deutschlands größter Kirchenkomponist «! Det 19. århundredes kirkemusikalske reform- eller restaurationsbevægelse i Tyskland inddeler sig således $\mathrm{i}$ to: en »ældre« og en »yngre«; den første fra 1840-1870, den sidste fra 1870'erne til fremkomsten af den 'kirkemusikalske modernisme' omkring 1920.

I Danmark kom det 19. århundredes diskussion om kirkemusikkens fornyelse til at forløbe på en helt egen måde. Ganske vist vågnede også her interessen for den gamle kirkemusik, især den 
italienske (Palestrina); med oprettelse af en Cæciliaforening efter tysk forbillede (Henrik Rung). Men denne interesse for den gamle latinske kirkemusik fik ikke nogen direkte indflydelse på datidens kirkesang $\mathrm{i}$ Danmark. Eller anderledes sagt: beskæftigelsen med den gamle katolske kirkemusik ledte ikke (som i Tyskland) automatisk over i en besindelse på den gamle lutherske kirkesang - og dermed hele spørgsmålet og diskussionen om den »rytmiske koral«. Det skyldes ganske enkelt, at spørgsmålet om en kirkesangens fornyelse i Danmark på dette tidspunkt (fra 1840'erne) allerede var rejst; ikke som et spørgsmål om den »stive koral« contra den »rytmiske«, men derimod som et spørgsmål om den romantiske salmetone (Vartov-sangen, Berggreen, Rung, Barnekow m.fl.) som et alternativ til den "stive koral « - og her ikke mindst de romantiske salmekomponisters indbyrdes stridigheder om kvaliteten af hinandens melodier. Behovet for og fremkomsten af nye melodier til Grundtvigs salmer resulterede med andre ord $i$, at hele debatten om den rytmiske koral i Danmark blev »forsinket « med 40 år! $!^{17}$ Det vil dermed sige, at mens tyskerne i deres forsøg på at skabe fornyet liv i kirkesangen så godt som udelukkende var henvist på historiske rekonstruktioner, fik kirkesangen i Danmark altså tilført en ny livskraft gennem de melodier, der fremkom med den grundtvigske salmesang.

Men netop de romantiske kirkemelodiers voksende udbredelse betød, at de gamle koralmelodier (i deres »stive form«) kom til at virke stadig mere fremmedartede og anakronistiske $\mathrm{i}$ den danske gudstjeneste. Det var den situation, organisten ved Helligåndskirken (fra 1890 ved Holmens Kirke), Thomas Laub tog udgangspunkt i, da han første gang fremsatte sine synspunkter for en reformering af den danske kirkesang i bogen Om Kirkesangen (1887). Hvad Laub her først og fremmest slår til lyd for, er en rehabilitering af de gamle koralmelodier i deres oprindelige rytmik og harmonik - ganske som den »ældre « tyske reformbevægelse havde gjort det 40 år tidligere. Forbavsende er det imidlertid, at Laub (på et tidspunkt, hvor den Bach'ske kirkemusik i Tyskland var blevet kåret som den lutherske kirkemusiks absolutte højdepunkt) ihærdigt fastholder det grundlæggende i Carl von Winterfelds kirkemusikalske anskuelse: at tiden efter 1600 repræsenterer en kirkemusikalsk forfaldsperiode; den lutherske kirkemusiks højdepunkt er at finde i det 16. århundredes vokalpolyfoni. 
Det er under tiden blevet hævdet, at det var den grundtvigske præst ved Helligåndskirken, Thomas Skat Rørdam (siden Holmens provst og Sjællands biskop), der skulle have sat Laub på sporet af denne kirkemusikfornyelse; nemlig under henvisning til salmemelodierne som en endnu uopdyrket side af den grundtvigske salmesangsfornyelse. ${ }^{18}$ Sagen er dog snarere den, at Laub har ladet sig direkte inspirere af de kirkemusikalske reformbevægelser, der gennem et halvt hundrede år allerede havde stået på i Tyskland. Hertil kommer, at Laubs Om kirkesangen fra $1887 \mathrm{i}$ betragtelig grad synes påvirket og inspireret af Carl von Winterfelds: Über Herstellung des Gemeineund Chorgesanges in der evangelischen Kirche fra 1848 (en miniudgave af tre-binds værket Der evangelische Kirchengesang). Endelig må det pointeres, at Laub i sit første kirkemusikalske skrift på ingen måde giver udtryk for noget bevidst grundtvigsk standpunkt (ud over den ret trivielle konstatering af, at Grundtvig har fået folk til at synge igen). Hvad Laub havde for $\varnothing j$ je med kirkesangen i 1887 var, om ikke kun, så dog primært af musikalsk-filologisk art.

I årene efter bogen Om kirkesangen tog Laub for alvor fat på at rekonstruere de gamle salmemelodier efter deres historiske forbilleder. ${ }^{19}$ Men hvad der først og fremmest skal interessere i denne sammenhæng, er Laubs egne melodier til Grundtvigs salmer.

\section{Laub som grundtvigsk salmekomponist}

Når Laub allerede i slutningen af 1880'erne begyndte at skrive melodier til Grundtvig-salmer, må det igen ses som foranlediget af hans beskæftigelse med de gamle kirkemelodier. Fordybelsen i den gammelprotestantiske musik måtte før eller siden føre til en kritik af de romantiske Grundtvig-melodier, og dermed også fremkalde et behov for en række alternative melodier. Disse nye melodier til Grundtvigs salmer blev for langt størstepartens vedkommende til i Laubs sidste år (fra 1910 til 1927); alene årene 1915-1917 tegner sig for 31 af Laubs originale Grundtvig-melodier (jvf. note 1). Hvad var baggrunden for, at Laub netop i disse år kastede sig over Grundtvigs salmetekster? En første forklaring kan være det samarbejde, Laub på dette tidspunkt havde indledt med Carl Nielsen omkring en række danske folkelige sange (En Snes danske Viser, I-II, 1915 og 1917). Det vil altså sige en periode, hvor beskæftigelsen med den folkelige 
sang var i højsædet - eller mere præcist: hvor Laubs arbejde gennem tredive år med såvel den klassiske kirkesang som den middelalderlige folkesang nu for alvor kunne bære frugt i skikkelse af originale kompositioner (både til den kirkelige og til den folkelige sang). Men ligeså vigtig er formentlig Laubs »opdagelse« af Grundtvig og det grundtvigske, dvs. opnåelsen af en dybere forståelse for Grundtvigs salmedigtning; en indsigt, der som nævnt er fraværende i Om kirkesangen fra 1887, men som da til gengæld træder desto tydeligere frem i bogen Musik og kirke fra 1920. Her udtrykker Laub kort og prægnant sin forståelse af Grundtvigs kirkelige indsats:

Ingen har som Grundtvig haft sans for den historiske sammenhæng gennem tiderne. Alt åndeligt, alt levende havde for ham et levnedsløb. Og det gælder da ikke mindst kirken, hvis liv han så som en enhed, en helhed, også forstået på den måde, at hvis der efter en død tid trængtes til fornyelse, var midlet ikke det at opfinde splinternye livskræfter, nej det det kom an på, var at vende tilbage på den gamle kirkegrund, så skulde det nye der trængtes til nok vokse frem, måske i ydre form forskelligt fra de ældre foreteelser men aldrig med et indhold af en anden ånd, aldrig i modsigelse af det oprindelige. ... Og hans egen sang, den ny sang, er som en stemme, lagt til det store fælleskor, udfyldende og berigende dets samklange, aldrig skurrende imod det, i åndelig énhed med det.

Men nu melodierne, gælder det samme dem? er de opståede på den fælles kirkegrund, er de bårne af den ånd, der har fyldt oldtidens, middelalderens og reformationens sang? Nej, og atter nej. Grundtvigs salmeord i deres sammenhæng med det fælleskirkelige er den hårdeste, den klareste dom over melodierne, der ganske mangler denne sammenhæng. (s. 132)

Med 'melodierne' mener Laub naturligvis de romantiske Grundtvigmelodier, der nu i Musik og kirke udsættes for en åbenlys og generel kritik, der sammenfattende består $i$, at disse melodier mere tager sigte på at skabe patetiske stemningsbilleder end at understøtte teksten. Men det afgørende i ovenstående citat er den parallel mellem tekst og musik, som Laub hævder nødvendigheden af. Ligesom Grundtvigs salmer er blevet digtet under inspiration af den gammelkirkelige 
tradition, således må også deres melodier være i harmoni med den gamle kirketone.

Det må de for overhovedet at komme overens med den tekst, de har til opgave at give musikalsk liv. Det er kort og godt det klassiske spørgsmål om form og indhold, talen er om. Er man indforstået med, at form (melodi) og indhold (tekst) bør stemme nogenlunde overens med hinanden, må man også forpligte sig på de forlangender, indholdet stiller til formen for at denne kan være fyldestgørende. Og dermed kommer det til at handle om, hvad der rent faktisk står i Grundtvigs salmetekster. Striden om romantiske melodier contra 'melodier i kirkestil' står og falder derfor med spørgsmålet om, hvilken af de to melodityper, der i størst omfang formår at tilgodese salmernes tekstlige indhold.

Den fundamentale svaghed ved de romantiske salmemelodier er at finde i deres reduktionistiske fremfærd i forhold til teksten. Fremfor at overveje salmen som helhed, begrænser denne meloditype sig ofte til udpenslingen af et enkelt poetisk motiv.

Et klassisk eksempel herpå er Barnekows melodi fra 1859 (DDK 249) til Kom, Gud Helligånd, kom brat fra 1837. Barnekows melodi er helt igennem præget af romancens smægtende ekspressivitet, der tydeligvis (og især hvad angår 2. linie) er tilegnet indholdet i salmens første strofe. Eller som Arthur Arnholtz har udtrykt det: »For rigtig at illustrere det ene ord i første strofe: 'gennembryd', giver han [Barnekow] det en spændt ledetone, som saa maa slæbes med til de $\emptyset$ vrige tekststrofer, hvor den virker umotiveret og kunstlet ${ }^{20}{ }^{20}$ Hvad man over for sådanne løsrevne motiver kunne betegne som salmens »kontekstuelle helhed «, er melodien helt ude af stand til at fange. Der er i Barnekows melodi intet som helst, der lader ane, at udtryk som »den mørke nat « og »hjertets lærkeslag « her har deres betydning og funktion $i$ en helt bestemt sammenhæng: nemlig $i$ en helligåndssalme af Grundtvig - og ikke i en vaudeville af Erik Bøgh! Som i så mange af de romantiske Grundtvig-melodier består den afgørende svaghed i melodiens ensidige focusering på billedlige udtryk, der i salmen netop fungerer som billeder; som midler til at udtrykke det egentlige (bønnen om Helligåndens komme), men som i den romantiske melodi bliver ophøjet til mål i sig selv.

Af en ganske anderledes karakter er Laubs melodi fra omkring 1910 efter en sekvens fra det 12. århundrede (DDK 250). Umiddelbart interessant er det her, at på samme måde som Grundtvigs salme 
er en gendigtning af den middelalderlige pinsesekvens Veni, sancte spiritus, griber også Laub tilbage til den middelalderlige sekvens. I kraft af sekvensmelodiens kirketonale (doriske) karakter, er det således en middelalderlig grundtone, der præger Laubs melodi. Netop melodiens kirketonale islæt er med til at give melodien rum; den doriske melodiføring skaber en dimension af højde og bredde, der uvilkårligt rækkes videre til teksten, når salmen synges. Vigtigt synes det også, at Laubs melodi i ganske særlig grad er med til at sikre Grundtvig-salmen dens integritet som 'Helligåndssalme i pagt med den gammelkirkelige tradition'. Den omtalte Barnekow-melodi lader aldeles hånt om salmens genese (og dermed også en væsentlig del af salmens egen intention); til fordel for et romantisk stemningsmaleri, der snarere modsiger salmens indhold fremfor at potensere det.

Et andet eksempel på en fornem Laub-melodi til en Grundtvigsalme er Vanaret vor drot kom i sin grav (DDS 236; jvf. GSV V 125: Guds-Ordet gik rundt, som Mand af Muld). Eksemplet er ydermere interessant af den grund, at det var Laub selv, der i 1915 sammen med melodien publicerede salmen i den version, vi i dag finder i salmebogen (Højskolebladet 1915, s. 625). Grundtvigs salme fra 1860 er et storslået eksempel på den modne Grundtvigs suveræne fremstilling af centrale teologiske temaer som Opstandelsen, Himmelfarten og Pinseunderet i dramatisk-poetiske billeder. Laubs melodi er igen udpræget kirketonal (dorisk), men med en levende rytmik, der bærer præg af en art folkelig kædedans, og som i særlig grad er med til at understrege betydningen af det »levendegørende Guds-ord «, salmen synger om. Det er svært at forestille sig, hvem der skulle kunne have skaffet denne Grundtvig-salme en bedre melodi.

Dette blot som en antydning af, hvordan Thomas Laub, inspireret af et ideal om kirkemusikken som en symbiose af gregorianikkens melodik, folkevisens rytmik og renaissance-polyfoniens harmonik, formåede at skabe en række melodier, der kan rumme den kompleksitet, der også kendetegner Grundtvigs salmer.

$\mathrm{Nu}$ gælder det unægteligt både for Grundtvig og for Laub, at en række af deres »historiske « forbilleder har vist sig at være uholdbare - eller i bedste fald udokumenterbare. Det væsentlige er imidlertid ikke, hvorvidt den opstandne Kristus som historisk faktum overgav disciplene den apostolske trosbekendelse, eller i hvilket omfang, Luther og hans umiddelbare efterfølgere med historisk sikkerhed sang 
rytmiske koraler. Det altafgørende er de positive resultater, disse idealer udmundede i: Grundtvigs genskabelse af et gudstjenstligt rum, hvor det er Herrens Ord, der lyder levende og klart; Laubs genskabelse af en salmetone, der er passende for menighedens respons på dette ord.

Netop påpegningen af disse forbilleders mere eller mindre relative historiske gyldighed, gør det relevant at spørge efter, hvad der da giver de historiske rekonstruktioner, »afbillederne«, deres aktuelle værdi. Svaret lyder, at det i sidste instans handler om historiske rekonstruktioner, der er "på højde med tiden «, hvilket vil sige: at de (bevidst eller ubevidst) har taget højde for de samtidige betingelser, de er blevet til inden for. Noget sådant blev tidligere antydet omkring Grundtvigs salmedigtning, men også Laubs melodier er umiskendeligt farvet af den senromantiske tone, der var hans egen tids. De være nok så inspirerede af reformationstidens rytme, tone og harmoni; hvad der knytter det hele sammen, er ikke desto mindre Laubs egen kunstneriske kraft. Ikke historiske forbilleder, men komponistens 'æstetiske dømmekraft' har fået det sidste ord i melodiernes brug af historiske elementer - såvel i rekonstruktionen af de gamle som i Laubs originale melodier. ${ }^{21}$ Med andre ord: det er denne '4. dimension', den kunstnerisk-æstetiske, der får de historiske komponenter til at blive til levende virkelighed, hvilket tillige er ensbetydende med aktuel gyldighed.

Denne 'aktuelle gyldighed' lader sig da også genfinde i den danske folkekirkelige praksis. Det kan kort illustreres ved en række højtidssalmer med tekst af Grundtvig og melodi af Laub.

Det gælder til Juledag: $N u$ vil vi sjunge og vare glad (1); til Fastelavnssøndag (Jesu Dåb): Alle mine kilder skal vare hos dig (2); til Skærtorsdag: Går det, Herre, som jeg vil (3); til Langfredag: Hil dig, Frelser og forsoner (4); til Påskelørdag: H $\phi r$ vor Helligaftens bøn (5); til Påskedag: Herren af søvne opvågned, opsprang (6); til Søndag efter Påske: Brat, Herre Jesus, blandt dine du stod (7); til Kristi Himmelfartsdag: Vaj nu, korsets flag, på voven (8), og endelig til Pinsedag: Vanaret vor drot kom i sin $\operatorname{grav}(9)$. 
Disse hovedsalmer til kirkeårets højtider viser frem for noget, i hvor høj grad den danske kirkesang er blevet præget af Grundtvig og Laub. Hertil kan føjes Sov sødt, barnlille (dåb) (10) og $O$, du Guds Lam (nadver) (11); af de mest kendte Grundtvig/Laub-salmer må desuden nævnes: Alt, hvad som fuglevinger fik (12), Alt står $i$ Gud Faders hånd (13), Det er så yndigt at følges ad, hvor banet vejen (14), Fuglen har rede og raven har grav (15), Lyksaligt det folk, som har фre for klang (16), Med sorgen og klagen hold måde (17), Morgenstund har guld $i$ mund (18), Vidunderligst af alt på jord (19), samt Vor Herre! til dig må jeg ty (20).

Brugen af Grundtvig-salmer og deres Laub-melodier er naturligvis lokalt varierende, men det her eksemplificerede antal tør gælde som et minimum. Hertil kommer ydermere de Grundtvig-melodier, Laub har komponeret efter gamle forlæg (eksempelvis Giv mig, Gud, en salmetunge og Denne er dagen, som Herren har gjort, samt den tidligere omtalte Kom, Gud Helligånd, kom brat). Medregner man nu de melodier, Laub har skrevet til tekster af andre salmedigtere (Sthen: Hvem skal jeg klage mit sorgfulde mod; Kingo: Tidens skrider, dägen rinder og Hvilestunden er $i$ vente; Brorson: (bl.a.) Det er den daglig trøst, samt Wexels: Stat op, min sjal, i morgengry), da bliver det endelige resultat, at Laub tegner sig for mindst 25 originale salmemelodier, der er i dag er i aktiv brug i den danske gudstjeneste.

Det er en »rekord « $i$ to henseender. For det første ligger Laub dermed på en absolut førsteplads, hvad angår brugen af melodier af en enkelt komponist i Den danske Koralbog (1954). ${ }^{22}$ For det andet vil det sige, at over en fjerdedel eller mere end 25 procent af Laubs originale salmemelodier til dags dato har vist sig praktisk anvendelige på længere sigt. Det er en rekord, sammenlignet med andre salmekomponisters gennemslagskraft og levedygtighed. Eksempelvis er der for Carl Nielsens vedkommende tale om mindre end 10 procent; for Berggreen bliver tallet endnu lavere.

Det må vække til eftertanke, at Thomas Laub - ud over at være den, der har skrevet det største antal praktisk anvendte salmemelodier i Danmark - samtidig også er den danske kirkekomponist, der har fremsat de mest reflekterede synspunkter for, hvad kirkemusik overhovedet er og bør være. Disse standpunkter er hos Laub dybt forankret $\mathrm{i}$ videnskabelige studier af både teologisk og musikhistorisk art. Men nok så vigtig er Laubs opfattelse af det personlige forhold, 
en salmekomponist må have til den aktuelle gudstjeneste-situation, dersom forehavendet skal lykkes efter hensigten.

I et brev til Thorvald Aagaard fra efteråret 1917 berører Laub dette emne. Den konkrete anledning er Laubs uenighed med vennen Carl Nielsen i spørgsmålet om salmemelodier. Laub skriver:

»For et par år siden lavede C. N. 50 salmemelodier, som han viste mig. Jeg var ikke glad ved dem og bad ham vente til vi sammen havde studeret den klassiske kirkesang. Han har i disse år betænkt sig på tingen, og - ikke forandret sin mening, og jeg jo da heller ikke min. Vi forstår ikke hinanden og det er en pine for os bægge. Jeg tror at man skal være »barn af huset«, elske dets skatte, selv have brugt dem (talt til Gud gennem dem), ellers véd man ikke hvad der trænger til og hvor man skal tage det fra. Ja det må vi tale om, når vi ses...« $(18.10 .1917)$

Dette brevuddrag giver måske det klareste udtryk for Laubs syn på kirkesangen og dens melodier. Kirkemusikkens hovedformål er ikke, som det hed hos Berggreen, at "sætte Sindet i en religiøs Stemning " og »røre til Andagt «, men at tjene som redskab for menighedens svar på evangeliet (og dermed menighedens samtale med Gud). I modsætning til romantikernes syn på kirkemusikken som et middel til religi$\emptyset \mathrm{s}$ introvertering, har kirkesangen i Laubs forståelse primært sin betydning som en extrovertering; nemlig som den sang, hvori menigheden hen-vender sig til Gud midt i gudstjenesten.

Det er her, forbindelsen til Grundtvig bliver umiddelbart indlysende. På samme måde som Grundtvig insisterer på den gudstjenstlige situation som kristendommens egentlige 'sted' (fremfor både den objektive videnskabeliggørelse og den subjektive selvfordybelse), således insisterer Laub på netop denne gudstjenestes historiske og aktuelle virkelighed som det endegyldige kriterium for kirkesangens musikalske udformning. Grundtvigs og Laubs stilling i nutidig dansk kirkesang er formentlig den bedste målestok for en vurdering af standpunkternes holdbarhed. 
Det blev nævnt til indledning, at Grundtvigs og Laubs poetiske og musikalske fornyelse af den danske kirkesang i tiden efter Oplysningen udgør et parallel-forl $\varnothing b$, samt at denne sideløbende udvikling tillige må ses som en afgørende forudsætning for den kongenialitet, der kan iagttages mellem Grundtvigs salmer og Thomas Laubs melodier. Afslutningsvis skal denne tankegang kort summeres op.

Det blev skitseret, hvordan Grundtvigs salmedigtning er foregået $i$ takt med hans egen teologiske udvikling. Denne udvikling startede i et romantisk opgør med oplysningstidens fornuftsteologi, hvorefter fulgte et gammelluthersk opgør med romantikkens æstetiske og panteistiske religiøsitet, og endelig blev Grundtvigs gammellutherske teologi overbudt af Grundtvigs egen genopdagelse af kristendommen som Guds-ordets levende virkelighed i de gudstjenstlige handlinger.

Et tilsvarende udviklingsforløb lader sig iagttage i Thomas Laubs arbejde med kirkemusikken. Det var den romantiske kirkesang, der »brød det isdække«, rationalismens døde koral havde lagt over kirkesangen ${ }^{23}$, ligesom det var 1800-tallets romantiske interesse for historien, der var forudsætningen bag Laubs beskæftigelse med de gammellutherske kirkemelodier. Men det egentlig originale hos Laub blev - i lighed med Grundtvig - hans egen videreførelse af arbejdet med det historiske; i form af selvstændige melodikompositioner. Dette var for Laubs vedkommende næppe blevet til noget, hvis ikke han havde haft Grundtvigs salmer som inspirationskilde - når den tyske reformbevægelse aldrig nåede længere end til rekonstruktionen af de gamle melodier, skyldtes det naturligvis, at man ikke samtidig fik en række tekster, der kaldte på et nyt melodistof i den gamle ånd.

Sammenligningen af Grundtvig og Laub begrænser sig naturligvis af de forskelle, der såvel fagligt som tidsligt består mellem dem. Alligevel er der grundlæggende tale om et fælles arbejdsprogram; nemlig at al kirkelig fornyelse må foregå ved at »vende tilbage på den gamle kirkegrund«, for så at lade det nye vokse frem på denne grund - »måske i ydre form forskelligt fra de ældre foreteelser men aldrig med et indhold af en anden ånd, aldrig i modsigelse af det oprindelige «.

Det er det manglende fodfæste på denne grund, der er de romantiske kirkemelodiers afgørende svaghed. Man kunne her sige, at de generelt betragtet blev stående i opgøret med rationalismens kirke- 
sang, uden at gøre 'det grundtvigske trin' med! - At det rent faktisk var de romantiske melodier, der blev sunget i Grundtvigs egen levetid (og øjensynligt med Grundtvigs bifald), er uden saglig betydning. Myten om, at man til en salme så vidt muligt skal holde sig til den mest »samtidige « melodi, er uholdbar. Intetsteds står det skrevet, at de musikalske midler, der var for hånden på det tidspunkt, hvor en salme blev digtet, også nødvendigvis er dem, der bedst formår at levendegøre den ånd, der er til stede i det tekstlige indhold. En melodis »samtidighed « med en tekst beror ikke på dens kontemporaritet, men på dens kongenialitet. At sætte lighedstegn mellem disse to egenskaber, ville have helt uoverskuelige konsekvenser.

Det er ikke ensbetydende med, at det romantiske melodirepertoire intet har bibragt den danske kirkesang af blivende varighed. På dette punkt har Laubs selektive fremfærd vist sig alt for rigoristisk. ${ }^{24}$ Men det ændrer imidlertid ikke noget ved det rigtige i Laubs principielle indvendinger mod den romantiske musik i gudstjenstlig sammenhæng. Det bør fastholdes, at den romantiske tone som sådan er »ukirkelig « - i den forstand, at den »vil« noget andet end blot bære teksten frem; nemlig suggerere »indre rørelse «. Og det behøver man strengt taget ikke umage sig i kirke for at opnå! Her er det da ikke mindst Thomas Laubs fortjeneste at have formuleret et teoretisk og praktisk begreb om en musikalsk kirkestil. Denne moderne kirkestil (thi den er skabt på moderne præmisser) er ikke alene årsagen til, at vi i dag overhovedet har en form for kirkemusikalsk stilbevidsthed; den kan ydermere tilskrives en ikke ubetydelig hermeneutisk vardi i forhold til helhedsforståelsen af Grundtvigs salmer.

Som epilog til temaet »Grundtvig og Laub som moderne gudstjeneste-fornyere « vil vi til slut lade Arthur Arnholtz få ordet:

Romantikkens første frugt var dens kunst; dens anden, senere modne, var den historiske kunstforskning, herunder den poetiske og musikalske hymnologi. Dens repræsentanter herhjemme var de to lærde kunstnere: Grundtvig og Laub. ${ }^{25}$ 
Noter

1 Med »originale salmemelodier « menes de melodier af Laub, der findes i Dansk Kirkesang, gamle og nye Melodier (1918), samt i Tillaeg til Dansk Kirkesang (1930). Det gængse tal »100« skyldes Laubs biograf, Povl Hamburger, Thomas Laub - hans Liv og Gerning, København 1942, s. 82 og 107. Strengt taget rummer de to ovennævnte samlinger imidlertid 101 originale Laub-melodier; Povl Hamburger har i sin optælling formentlig set bort fra melodien til $O, d u$ Guds Lam, der i Dansk Kirkesang er anbragt under nadverliturgien. - Hertil kan yderligere føjes Laubs melodier til Grundtvigs I falmede blade og I kvald blev der banket på Helvedes port, der siden har fået tildelt status af kirkesalmer (jvf. 46 Salmer - Tillag til Den danske Salmebog, udgivet af Kirkeligt Samfund og Samfundet Dansk Kirkesang, 1976, nr. 757 og 768).

2 Om Religion og Liturgie (1807), Holger Begtrup: N. S. F. Grundtvig. Udvalgte Skrifter, I, København 1904, s. 139-40.

3 Jvf. Om Religion og Liturgie, s. 138.

4 Jvf. Christian Thodberg: »Digtet 'De levendes Land' belyst ud fra Grundtvigs prædikener og den bibelske poesi«, Syn og Sang, København 1989, s. 189-90.

5 Jvf. Om Religion og Liturgie, s. 142 og 145.

6 »Liturgien inddeler sig selv i den opløftende og undervisende. Hin kan forene sig med denne, men denne aldrig med hin uden Skade for begge $\ll$, ibid., s. 159.

7 Ibid., s. 166.

$8 \quad$ Udvalgte Skrifter, 2, s. 77.

$9 \quad$ Ibid., s. 79.

10

»Om Aabenbaring, Konst og Vidskab«, Danne-Virke III, s. 266-67.

11 Ibid., s. 262.

12 Det gælder først og fremmest prædikenerne frem til »den mageløse opdagelse « (dvs. fra starten af Grundtvigs virke som prædikant ved Vor Frelsers Kirke i 1822); se hertil Christian Thodberg: „Grundtvig som 
salmedigter«, Grundtvig og grundtvigianismen i nyt lys, Århus 1983, s. $169 \mathrm{ff}$.

13 Jeg henviser her til følgende afhandlinger af Chr. Thodberg: »Omkring Sangværkets tilblivelse«, Syn og Sang, 1989, s. 139ff., samt "Grundtvigs græske vækkelse og Sangværket«, Dansk Kirkesangs Årsskrift 1989-93, s. $10 \mathrm{ff}$.

C. I. Scharlings værdifulde bog, Grundtvig og Romantiken - belyst ved Grundtvigs Forhold til Schelling, København 1947, er samtidig én lang fremstilling af Grundtvigs teologiske opgør med romantikkens kunst- og naturreligiøsitet.

15 Her er det mindre afgørende, i hvilket omfang Grundtvig rent faktisk havde forstået den gammellutherske teologi, samt hvorvidt hans explicitte kritik heraf fra 1832 på alle punkter er træffende (i hvert fald er hans tolkning af den luthersk-ortodokse arvesyndslære som »menneskenaturens totale fordærvelse« urigtig). Det vigtige er imidlertid de konstruktive resultater, denne og andre »historiske vildfarelser« hos Grundtvig gav anledning til.

16 A. P. Berggreen: Melodier til den fra Roeskilde Prasteconvent udgaaede »Psalmebog til Kirke- og Huus-Andagt« og til »Evangelisk-christelig Psalmebog«, 1853, s. XIII.

17 Bemærkelsesværdigt er det, at der allerede i 1850'erne (dvs. i umiddelbar forlængelse af den tyske diskussion) opstod en debat om genindførelsen af den 'rytmiske koral' i Norge og kort tid efter også i Sverige. I Danmark nøjedes Berggreen med at henvise til den tyske diskussion som »en Strid«, der er »ført med stor Eensidighed «, Om menighedssangen, s. XVII; selv gjorde han sig til talsmand for en højst moderat rytmisering af salmemelodierne, og anbefalede så i $\emptyset$ vrigt det »levende Foredrag « som middel til at afhjælpe den stive korals alt for 'unaturlige Langsomhed'.

Således Jørgen I. Jensen: »Laub var grundtvigsk teolog «, Dansk Kirkesangs Årsskrift 1983-84, s. 117f.

19 I første omgang i alt 125 koralmelodier; udgivet i tre samlinger 1888-90. Til Laubs arbejde med det gamle melodistof giver Laubs korrespondance med Otto Kade (1819-1900, musikdirektor i Schwerin) en fortrinlig belysning; se Henrik Glahn: »Otto Kades breve til Thomas Laub 1889-1898«, med indledning og kommenteret oversættelse, Dansk Kirkesangs Årsskrift 1989-93, s. 71-141. 
Arthur Arnholtz: »Grundtvigs salmer og deres melodier«, Grundtvig-Studier 1952, s. 32.

21 Netop den frie omgang med det historiske har ofte bragt Laubs kritikere i vildrede; senest John Wedell Horsner, der i "På salmens tonestige" - 50 salme-essays (Dansk Kirkemusiker Forenings Forlag 1993) nedladende taler om Laubs fors $\emptyset$ g på at give sine melodiudsættelser et "pseudo-renæssancepræg « (s. 151). En sådan kritik kan imidlertid kun holdes for rammende, dersom det havde drejet sig om forsøget på at genskabe tingen præcis som den var (in casu renaissancens harmonisering); ikke hvis det handler om brugen af den samme ting som kilde til inspiration.

22 Til sammenligning tegner Berggreen sig for omtrent 10, Henrik Rung 7 og Carl Nielsen 5 melodier; stadigvæk beregnet ud fra det samme »minimumkriterium«. - At det samlede antal Laub-melodier i koralbogen, nemlig 74, er højt $\mathrm{i}$ forhold til den praksis, der afspejles i den kirkelige virkelighed, siger sig selv. At man fortsat kan argumentere for den praktiske anvendelighed af yderligere en 20-25 Laub-melodier, er en anden sag.

Om kirkesangen, København 1887, s. 98.

For en ordens skyld må det nævnes, at Laub i melodisamlingen Dansk kirkesang (1918) blandt i alt 207 numre kun medtog fire melodier fra den romantiske tradition, nemlig de velkendte melodier til Den signede dag (Weyse 1826), Kirken den er et gammelt hus (Lindemann 1840), Vaer velkommen, Herrens år (Berggreen 1852) og O, lad din Ånd nu med os vare (Rung 1857).

»Grundtvigs salmer og deres melodier«, s. 34. I sin store disputats om den liturgiske udvikling i Danmark; Vernieuwing in Drieklank - Een onderzoek naar de liturgische ontwikkelingen in Denemarken 1800 tot 1950 (Utrecht 1990), slutter den hollandske musikolog Frans Brouwer med nogle overvejelser over liturgiens kunstneriske dimension, og Brouwer afslutter det hele (s. 509) med motto'et:

Le savant cherche, l'artiste trouve!

I relation til Grundtvigs og Laubs liturgiske fornyelser, burde man måske snarere - i overensstemmelse med Arnholtz' formulering - overveje at omskrive dette motto til:

L'artiste savant cherche et trouve! 